\title{
The Study of the Synthesis of Nanosized Refractory Carbides by Carbothermal Reduction of Precursor Gels and their Characteristics
}

\author{
IImārs ZĀLĪTE *, Anita LETLENA, Laila ČERA, Ints ŠTEINS, Aija KR̄̄MIṆA \\ Institute of Inorganic Chemistry of the Riga Technical University, Miera 34, Salaspils, LV-2169, Latvia \\ cross $^{\text {ref }}$ http://dx.doi.org/10.5755/j01.ms.22.1.7473
}

Received 30 June 2014; accepted 30 May 2015

\begin{abstract}
In the present study, four refractory carbides $-\mathrm{TiC}, \mathrm{NbC}, \mathrm{TaC}$ and $\mathrm{SiC}$ - have been produced by carbothermal reduction of a precursor prepared by sol-gel and coat-mix $(\mathrm{SiC})$ process. Binary hydrogels, in which the oxide gel and a pyrolysable organic compound are combined, were prepared as precursors for synthesis of corresponding carbides. The phase structure, crystallite size, morphology and specific surface area of the synthesized powders are investigated by XRD, SEM and BET respectively. Spark plasma sintering (SPS) method (up to $1850{ }^{\circ} \mathrm{C}$, heating rate of $100{ }^{\circ} \mathrm{C} / \mathrm{min}$ and dwelling time of $5 \mathrm{~min}$.) was used for investigation of compacting of these carbides.

Keywords: transition metal carbide, $\mathrm{SiC}$, nanosized powders, synthesis, SPS sintering, properties.
\end{abstract}

\section{INTRODUCTION}

The carbides of the transition metals - Ti, Zr, Hf - are important ceramic materials used for high-temperature applications, due to their superior mechanical and electrical properties at elevated temperatures [ $1-3]$. These materials exhibit high strength, good chemical, corrosion and oxidation resistance.

It has been proved that in many cases properties of nanostructured materials differ from those for materials produced from conventional coarse-grained polycrystals with the same composition [4]. One of the ways to get materials with fine-grained structure is application of nanoparticles as a raw component in the compacting process [5].

Recently different methods of synthesis were used for production of nanopowders - hydrolysis, hydrothermal synthesis, pyrolysis, co-precipitation method, sol-gel method, high energy milling, microwave synthesis, plasma synthesis etc. [6-9]. Our research is focused on the investigation of chemical processing routes to obtain nanosized powders of carbides with a narrow particle size distribution.

In the present study, four refractory carbides - TiC, $\mathrm{NbC}, \mathrm{TaC}$ and $\mathrm{SiC}$ - have been produced by carbothermal reduction of a precursor prepared by sol-gel process.

\section{EXPERIMENTAL}

Binary hydrogels, in which the oxide gel and a pyrolysable organic compound are combined, were prepared as precursors for synthesis of corresponding carbides.

As shown in [10], the best results in the fabrication of TiC nanoparticles are obtained, when $\mathrm{Ti}$ isopropoxide, sucrose and acetic acid ( $\mathrm{Ti}: \mathrm{C}=1: 3.7$ ) as raw materials were used. Sucrose was dissolved in warm acetic acid

\footnotetext{
* Corresponding author. Tel.: +371-29-409431; fax: +371-67-800767.

E-mail address: ilmars@nki.lv (I. Zālīte)
}

$\left(T \sim 80{ }^{\circ} \mathrm{C}\right)$ and cooled to the room temperature. $\mathrm{Ti}$ isopropoxide was slowly added and stirred approximately for $3 \mathrm{~h}$. The excess of acetic acid was evaporated at $80^{\circ} \mathrm{C}$. Then it is possible to obtain $\mathrm{TiC}$ nanoparticles with a specific surface area of $50-100 \mathrm{~m}^{2} / \mathrm{g}$ (the heat treatment of $1350-1400{ }^{\circ} \mathrm{C}$ ) with a relatively small content of oxygen and free carbon.

For $\mathrm{NbC}(\mathrm{TaC})$ fabrication $\mathrm{Nb}(\mathrm{Ta})$ hydroxide was precipitated from a solution of $\mathrm{NbCl}_{5}\left(\mathrm{TaCl}_{5}\right)(0.01 \mathrm{~mol})$ in dilute $\mathrm{HCl}$ using ammonia. The hydroxide was washed, then suspended in water (at $0{ }^{\circ} \mathrm{C}$ for $\mathrm{Nb}$ and at room temperature for Ta) and treated with $\mathrm{H}_{2} \mathrm{O}_{2}$. After $1 \mathrm{~h} \mathrm{Nb}$ (Ta) peroxo acid had formed. Excess of $\mathrm{H}_{2} \mathrm{O}_{2}$ and water was removed by heating at $80^{\circ} \mathrm{C}$ and then sucrose solution ( $\mathrm{Nb}(\mathrm{Ta}): \mathrm{C}=1: 7.0)$ was added.

All the gels were dried at $100^{\circ} \mathrm{C}-110^{\circ} \mathrm{C}$, grinded and sieved through sieve, then heated in Ar flow with the heating rate of $(300-350)^{\circ} \mathrm{C} / \mathrm{h}$ until $1400{ }^{\circ} \mathrm{C}$ and treated for $1 \mathrm{~h}$.

The precursor for $\mathrm{SiC}$ synthesis ( $\mathrm{Si}$ particles covered by the layer of C) was prepared by the coat-mix processing. Si particles were mechanically mixed with phenolic or epoxy resin in a definite proportion and then thermally treated in Ar flow. At $1500{ }^{\circ} \mathrm{C}$ liquid Si reacts with $\mathrm{C}$ forming $\mathrm{SiC}$.

Chemical composition of the nanopowder ( $\mathrm{Ti}, \mathrm{Ta}, \mathrm{Nb}$, $\left.\mathrm{Si}, \mathrm{C}_{\text {total }}, \mathrm{O}\right)$ was determined by chemical analysis. Phase composition and crystallite size (the crystallite sizes were calculated from XRD using Scherrer formula) of the synthesized powders was performed via X-ray diffractometry (XRD) (Advance D8, Bruker AXS).

BET argon adsorption/desorption method was used for determination the specific surface area of nanopowders. Morphology and particle size of powder particles and microstructures of ceramic materials were investigated by the scanning electron microscope (SEM) Hitachi, S4800. Density of sintered samples was determined by the Archimedes method.

Samples of carbide ceramics were made by the methods of spark plasma sintering (SPS). Compacting by 
the SPS method was performed by the Toshiba equipment (Dr. SINTER, SPS-825.CE): at 1700 or $1850{ }^{\circ} \mathrm{C}$, heating rate of $100{ }^{\circ} \mathrm{C} / \mathrm{min}$ and dwelling time of $5 \mathrm{~min}$, cooling with furnace. The pressing pressure was of $30 \mathrm{MPa}$. Sintering was made in vacuum.

\section{RESULTS AND DISCUSSION}

Characteristics of produced powders (the heat treatment at $1400{ }^{\circ} \mathrm{C}$, for $\mathrm{SiC}-1500^{\circ} \mathrm{C}$ ) are given in Table 1. All products have a small content of oxygen and to reduce it the proportion $\mathrm{C} / \mathrm{Me}$ must be increased, but this increases the content of free carbon. If the conditions of synthesis are optimal (molar ratio of gel-derived $\mathrm{C}$ to $\mathrm{Me}$, heating rate and temperature and heat-treating time) $\mathrm{XRD}$ analysis of the produced products shows the presence of intensive carbide lines and only traces of oxide phases (Fig. 1). In the case of tantalum carbide also the traces of $\mathrm{Ta}_{2} \mathrm{O}_{5}$ have been found.

The results show that at an appropriate molar ratio of resin-derived $\mathrm{C}$ to $\mathrm{Si}$ high purity $\mathrm{SiC}$ can be produced. The colour of the powder is light grey, indicating that the free carbon content is low.

For all transition metal carbides the crystallite size of the carbide phase lies in the range of $45-65 \mathrm{~nm}$, only for silicon carbide this is of $12-15 \mathrm{~nm}$. The specific surface of carbides treated at $1400{ }^{\circ} \mathrm{C}$ (for $\mathrm{SiC}-$ at $1500{ }^{\circ} \mathrm{C}$ ) is of $25-35 \mathrm{~m}^{2} / \mathrm{g}$, but for TiC SSA reaches $65-70 \mathrm{~m}^{2} / \mathrm{g}$. The average particle size for all carbides is in the range of $40-60 \mathrm{~nm}$.

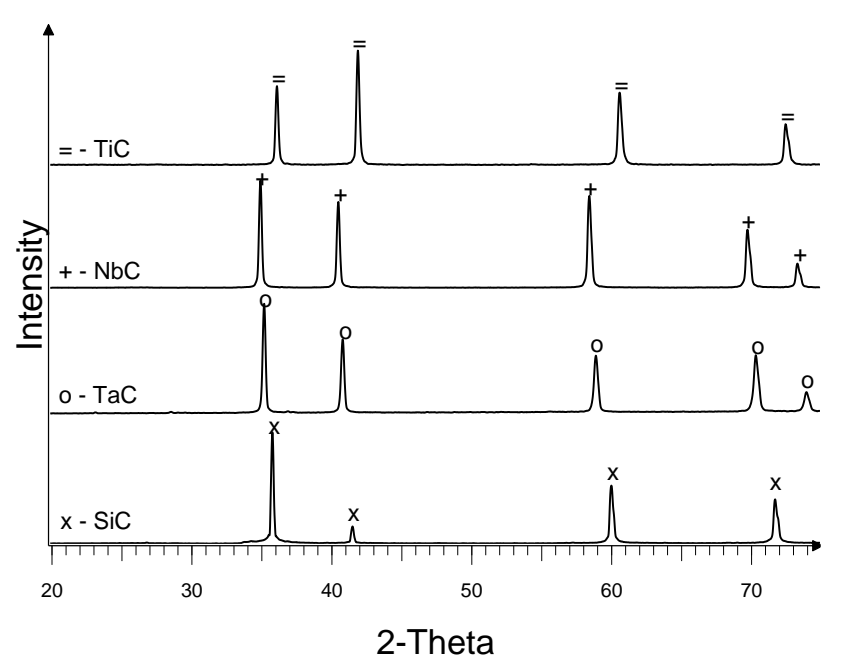

Fig. 1. XRD analysis of the produced products

In Fig. 2 there are the pictures of electron microscopy of these powders. For all transition metal (Ti, Nb, Ta) carbides the particle size is of approximately $50-150 \mathrm{~nm}$, but for $\mathrm{SiC}$ the particle size is in the range of 100-200 nm.

Characteristics of ceramic samples produced by the SPS sintering are given in Table 2. Intense shrinkage of material begins at $1080-1120^{\circ} \mathrm{C}$, finishing at $1700{ }^{\circ} \mathrm{C}$ (for $\mathrm{TiC}$ and $\mathrm{TaC}$ ceramics) (Fig. 3) and at $1400-1850{ }^{\circ} \mathrm{C}$ (for $\mathrm{NbC}$ ceramics). The sample density does not reach $100 \%$, probably due to the presence of free carbon in samples.

Table 1. Properties of synthesized carbide nanopowders

\begin{tabular}{|c|c|c|c|c|c|c|c|c|c|}
\hline \multirow{2}{*}{ Compound } & \multirow{2}{*}{$\begin{array}{l}\text { SSA, } \\
\mathrm{m}^{2} / \mathrm{g}\end{array}$} & \multirow{2}{*}{$\begin{array}{c}\mathrm{d}_{50} * \\
\mathrm{~nm}\end{array}$} & \multicolumn{5}{|c|}{ Chemical composition, wt.\% } & \multirow{2}{*}{$\begin{array}{c}\text { Phase } \\
\text { composition }\end{array}$} & \multirow{2}{*}{ Crystallite size, $\mathrm{nm}$} \\
\hline & & & $\mathrm{Me}$ & $\mathrm{O}$ & $\mathrm{N}$ & $\mathrm{C}_{\text {total }}$ & $\mathrm{C}_{\text {free }}$ & & \\
\hline $\mathrm{TiC}$ & $65-70$ & 50 & 76.6 & 1.7 & 0.1 & 21.5 & 1.6 & $\mathrm{TiC}$ & $45-50$ \\
\hline $\mathrm{NbC}$ & $30-35$ & 60 & 86.7 & 1.0 & 0 & 11.8 & 0.8 & $\mathrm{NbC}$ & $60-65$ \\
\hline $\mathrm{TaC}$ & $25-28$ & 40 & 91.7 & 0.6 & 0 & 6.7 & 0.7 & $\mathrm{TaC}$ & $40-45$ \\
\hline $\mathrm{SiC}$ & $25-30$ & 70 & 68.2 & 1.8 & 0 & 29.4 & 0.8 & $\beta-\mathrm{SiC}$ & $12-15$ \\
\hline
\end{tabular}

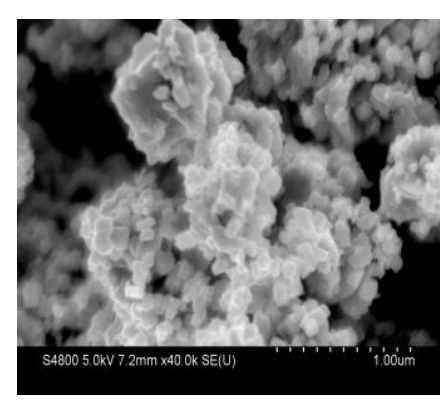

a

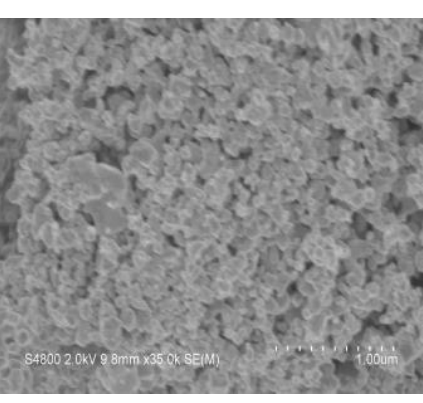

b

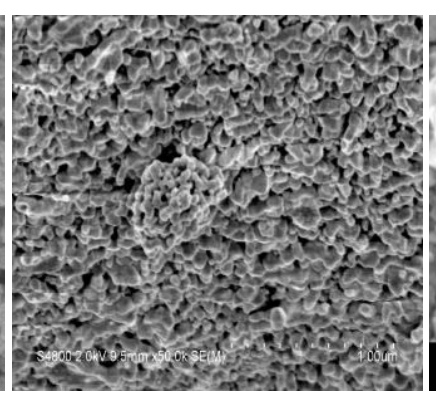

$\mathrm{c}$

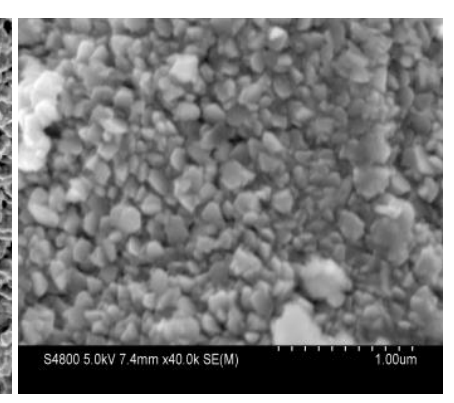

d

Fig. 2. Micrographs of nanopowders, obtained by chemical synthesis: $\mathrm{a}-\mathrm{TiC} ; \mathrm{b}-\mathrm{NbC} ; \mathrm{c}-\mathrm{TaC} ; \mathrm{d}-\mathrm{SiC}$

Table 2. Properties of SPS sintered carbide ceramics

\begin{tabular}{|c|c|c|c|c|c|c|c|}
\hline Compound & $\mathrm{T}_{\text {begin }}{ }^{\circ} \mathrm{C}$ & $\mathrm{T}$ end, ${ }^{\circ} \mathrm{C}$ & $\begin{array}{c}\text { Grain size, } \\
\mu \mathrm{m}\end{array}$ & $\begin{array}{c}\text { Density, } \\
\mathrm{g} / \mathrm{cm}^{3}\end{array}$ & $\begin{array}{c}\text { Open } \\
\text { porosity, } \%\end{array}$ & $\begin{array}{c}\text { Phase } \\
\text { composition }\end{array}$ & Crystallite size, $\mathrm{nm}$ \\
\hline $\mathrm{TiC}$ & 1120 & 1700 & $0.2-0.6$ & 4.0 & 5.3 & $\mathrm{TiC}$ & $60-70$ \\
\hline $\mathrm{NbC}$ & 1380 & 1850 & $0.6-1.0$ & 6.6 & 8.6 & $\mathrm{NbC}$ & $60-80$ \\
\hline $\mathrm{TaC}$ & 1080 & 1700 & $0.4-0.8$ & 14.1 & 0.4 & $\mathrm{TaC}$ & $50-60$ \\
\hline
\end{tabular}




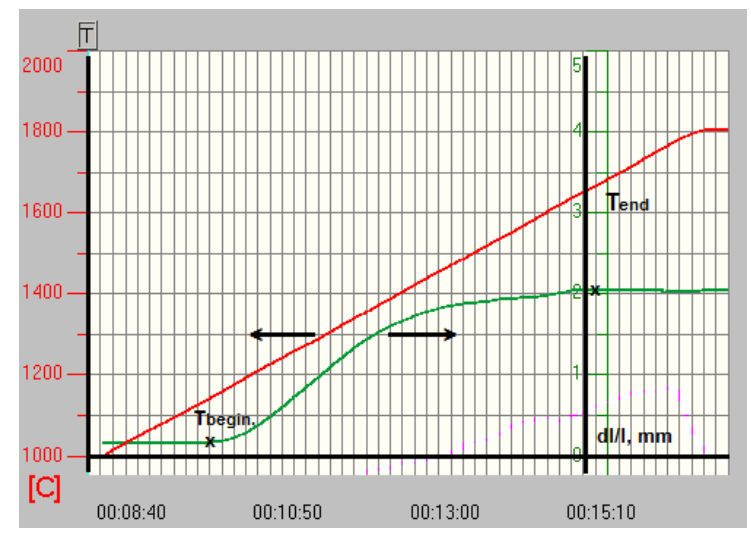

Fig. 3. Fragment of the shrinkage curve of titanium carbide in the range from $1000^{\circ} \mathrm{C}$ to $1800^{\circ} \mathrm{C}$ at the SPS process

The grain size of the ceramics is comparatively small (Fig. 4): for TiC ceramics the grain size is of $0.2-0.6 \mu \mathrm{m}$, when the crystallite size is of $60-70 \mathrm{~nm}$, for $\mathrm{NbC}-0.6-1.0 \mu \mathrm{m}$ and for $\mathrm{TaC}$ approximately $0.4-0.8 \mu \mathrm{m}$, when the crystallite size is of $60-80$ and $50-60 \mathrm{~nm}$, respectively.

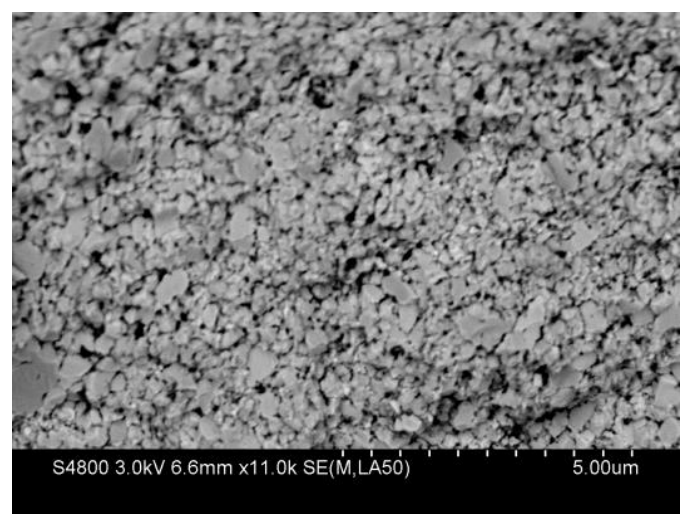

Fig. 4. Microstructure of the sample of TiC compacted at $1700{ }^{\circ} \mathrm{C}$ by SPS

A significant decrease of admixtures has been observed in ceramic material during sintering. For example, during sintering interaction between titanium oxycarbide and free carbon occur; therefore, ceramics consists of purer $\mathrm{TiC}$ (Fig. 5).

The obtained results are in good correspondence with the research of other authors, where nanopowders of $\mathrm{Ti}$, $\mathrm{Nb}$, Ta carbides are produced by different methods. Nanopowders with the particle size in the range of $20-100 \mathrm{~nm}$ were produced using reactions both in a solid, liquid or gas phase at low temperatures $\left(550^{\circ} \mathrm{C}\right)$ in autoclave $[11-13]$, both in liquid and solid phase reactions at temperatures up to $1350{ }^{\circ} \mathrm{C}[14-17]$. In spite of the relatively high temperature of synthesis, comparatively pure $\mathrm{Ti}, \mathrm{Nb}$ and $\mathrm{Ta}$ carbides of the cubic phase as well as $\mathrm{SiC}$ nanopowders also could be obtained by the descripted method.

It was found during investigations, that rapid consolidation of binderless nanostructured carbide by spark plasma sintering (SPS) or similar to this method pulsed current activated sintering (PCAS) [18] results in a material with relatively fine-grained structure.

Sintering temperature of produced nanosized carbides $\left(1700-1850^{\circ} \mathrm{C}\right)$ is significantly lower than sintering temperature of submicron carbides $[19,20]$.

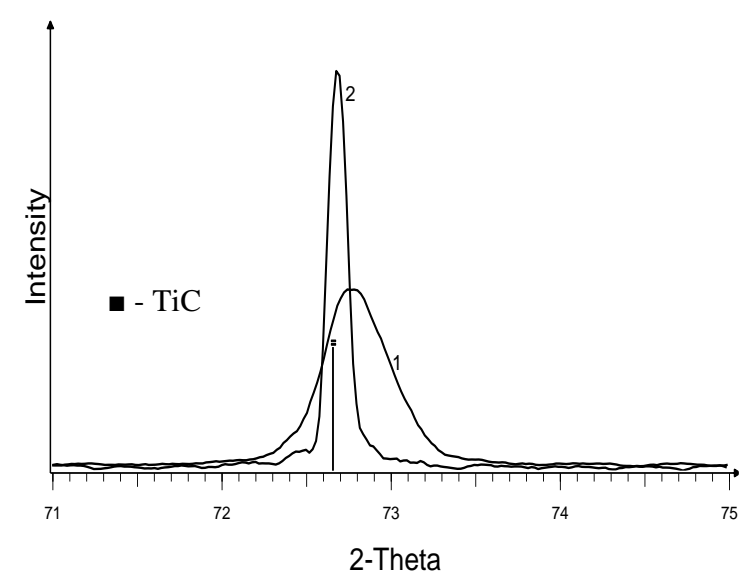

Fig. 5. Fragment of the phase composition of $\mathrm{TiC}$ nanopowder (1) and sample of $\mathrm{TiC}$ compacted at $1700^{\circ} \mathrm{C}$ by SPS (2)

\section{CONCLUSIONS}

Nanosized transition metal $(\mathrm{Ti}, \mathrm{Nb}, \mathrm{Ta})$ and silicon carbides were prepared. $\mathrm{Ti}$ isopropoxide, sucrose and acetic acid were used for sintering of TiC. For production of $\mathrm{NbC}$ and $\mathrm{TaC}$ the corresponding hydroxides are obtained from a solution of $\mathrm{NbCl}_{5}\left(\mathrm{TaCl}_{5}\right)(0.01 \mathrm{~mol}$.) in dilute $\mathrm{HCl}$ using ammonia, and carburized by sucrose. All carbides are produced by thermal treatment of the gel at $1400{ }^{\circ} \mathrm{C}$. $\mathrm{SiC}$ is obtained by the coat-mix processing from Si particles and phenolic or epoxy resin at $1500{ }^{\circ} \mathrm{C}$.

Synthesized one phase products are quite pure and contain small amount of oxygen and free carbon admixtures and the average particle size is of $40-70 \mathrm{~nm}$. Also the crystallite size of $\mathrm{Ti}, \mathrm{Ta}$ and $\mathrm{Nb}$ carbides are in the same range that would be the evidence that the produced particles are monocrystalline.

Sintering of carbide nanopowders by the SPS method results in a relatively dense material with the fine-grained structure (grain size up to $1 \mu \mathrm{m}$ ). In comparison with the submicron carbide powders, the sintering temperature $\left(1700-1850{ }^{\circ} \mathrm{C}\right)$ of produced nanosized carbides is noticeably lower.

They can be successfully utilized both for production of compact nanostructured materials, both as components for production of different kinds of composite materials.

\section{REFERENCES}

1. Lee, D.W., Alexandrovskii, S.V., Kim, B.K. Novel Synthesis of Substoichiometric Ultrafine Titanium Carbide Materials Letters 58 (9) 2004: pp. 1471-1474.

2. Dolle, M., Gosset, D., Bogicevic, C., Karolak, F., Simeone, D., Baldinozzi, G. Synthesis of Nanosized Zirconium Carbide by a Sol-gel Route Journal of European Ceramic Society 27 2007: pp. 2061-2067.

3. Woo, Y.C., Kang, H.J., Kim, D.J. Formation of TiC Particle during Carbothermal Reduction of $\mathrm{TiO}_{2}$ Journal of European Ceramic Society 27 2007: pp. 719-722. http://dx.doi.org/10.1016/j.jeurceramsoc.2006.04.090

4. Ettmayer, P., Kolaska, H., Lengauer, W., Dreyer, K. $\mathrm{Ti}(\mathrm{C}, \mathrm{N})$ Cermets - Metallurgy and Properties International Journal of Refractory Metals and Hard Materials 13 1995: pp. 343-351. 
5. Grabis, J., Zalite, I. Nanosize Powders of Refractory Compounds for Obtaining of Fine-grained Ceramic Materials Material Science Forum 555 2007: pp. $267-272$.

6. Rohmer, M.M., Benard, M., Poblet, J.M. Structure, Reactivity and Growth Pathways of Metallocarbohedrenes $\mathrm{M}_{8} \mathrm{C}_{12}$ and Transition Metal/Carbon Clusters and Nanocrystals: A Challenge to Computational Chemistry Chemical Reviews 100 (2) 2000: pp. 495-542.

7. Lei, M., Zhao, H.Z., Yang, H., Song, B., Tang, W.H. Synthesis of Transition Metal Carbide Nanoparticles through Melamine and Metal Oxides Journal of European Ceramic Society 28 2008: pp. 1671-1677.

8. Preiss, H., Berger, L.M., Schulze, D. Studies on the Carbothermal Preparation of Titanium Carbide from Different Gel Precursors Journal of European Ceramic Society 19 1999: pp. 195-206.

9. Preiss, H., Schulze, D., Klobes, P. Formation of NbC and $\mathrm{TaC}$ from Gel-Derived Precursors Journal of European Ceramic Society 17 1997: pp. 1423-1435. http://dx.doi.org/10.1016/S0955-2219(97)00012-5

10. Zalite, I., Letlena, A. Synthesis and Characterization of Nanosized Titanium Carbide by Carbothermal Reduction of Precursor Gels Materials Science (Medžiagotyra) 18 2012: pp. $75-78$.

11. Shia, L., Gua, Y., Chena, L., Yanga, Z., Maa, J., Qiana, Y. Synthesis and Oxidation Behavior of Nanocrystalline Niobium Carbide Solid State Ionics 176 2005: pp. $841-843$.

12. Chen, Y., Zhang, H., Zhang, J., Maa, J., Wangd, L., Ye, H., Qian, G., Ye, Y. Facile Synthesis, Characterization and Photocatalytic Activity of Niobium Carbide Advanced Powder Technology 24 2013: pp. 207-211.
13. Maa, J., Wu, M., Du, Y., Chen, S., Jin, W., Fu, L., Yang, Q., Wen, A. Formation of Nanocrystalline Niobium Carbide (NbC) with a Convenient Route at Low Temperature Journal of Alloys and Compounds 475 2009: pp. $415-417$.

14. Medeiros, F.F.P., da Silva, A.G.P., de Souza, C.P. Synthesis of Niobium Carbide at Low Temperature and its Use in Hardmetal Powder Technology 126 2002: pp. $155-160$.

15. Ma, M., Shen, W., Zhang, P., Zhang, J., Wang, Q., Ge, C. Synthesis of TaC Nanopowders by Liquid Precursor Route Materials Letters 65 2011: pp. 96-99.

16. Kwona, D.H., Hong, S.H., Kim, B.K. Fabrication of Ultrafine $\mathrm{TaC}$ Powders by Mechano-chemical Process Materials Letters 58 2004: pp. 3863-3867.

17. Lee, Y.J., Kima, S.H., Lee, T.H., Nersisyan, H.H., Lee, K.H., Han, M.H., Jeong, S.U., Kang, K.S., Bae, K.K., Lee, J.H. Combustion Synthesis and Characterization of $\mathrm{TaC}, \mathrm{TaC} / \mathrm{TaSi} 2$, and $\mathrm{TaC} / \mathrm{TaB}$ Nanoparticles Chemical Engineering Science 107 2014: pp. 227-234. http://dx.doi.org/10.1016/j.ces.2013.12.015

18. Shon, I.J., Kim, B.R., Ko, I.Y., Nam, K.S., Doh, J.M. Properties and Rapid Consolidation of Binderless Nanostuctured Tantalum Carbide by Pulsed Current Activated Sintering Journal of Ceramic Processing Research 11 (4) 2010: pp. 498-502.

19. Khaleghi, E., Lin, Y.S., Meyers, M.A., Olevsky, E.A. Spark Plasma Sintering of Tantalum Carbide Scripta Materialia 63 2010: pp. 577-580.

20. Zhang, X., Hilmas, G.E., Fahrenholtz, W.G. Densification and Mechanical Properties of TaC-Based Ceramics Materials Science and Engineering: A 501 2009: pp. $37-43$. 